\title{
Evaluation of the Etiology of Ocular Globe Atrophy or Loss
}

\author{
Viviane Regina CÔAS \\ Ana Christina Claro NEVES \\ Sigmar de Mello RODE
}

Department of Dentistry, University of Taubaté (UNITAU), Taubaté, SP, Brazil

\begin{abstract}
This survey investigated the etiology of atrophy or loss of the ocular globe in patients assisted at the Maxillofacial Prosthetics Clinic of two Schools of Dentistry in São Paulo State, Brazil. A total of 238 patients were examined and their clinical files were reviewed. The etiology of eyeball atrophy/loss was assessed with respect to gender, age group, affected side and type ophthalmologic surgery performed. The greatest incidence of ocular globe loss was due to traumatic etiology (57.14\%), followed by pathogenic (36.13\%) and congenital (5.04\%) etiologies. Comparing the genders, a predominance of male patients was observed (61.76\%; $<<0.01$ ). The age group most frequently affected was between 21 and 40 years $(42.01 \%$; $<0.01)$. For all types of etiologies investigated in this study, enucleation was the most commonly used surgical procedure for removal of the ocular globe (66.38\%; $<<0.01)$. Loss of the left eye was predominantly seen (55.04\%), even though no statistically significant difference was found between sides ( $>00.01)$.
\end{abstract}

Key Words: ocular bulb loss, artificial eye, ocular prosthesis.

\section{INTRODUCTION}

Ocular prosthesis is a modality of facial prosthesis that aims to repair total or partial ocular bulb losses or deformities. The main goals are to restore facial esthetics, prevent eyelid collapse and deformity, protect the socket against injuries caused by foreign bodies, dust and smoke, reestablish the correct route of the lachrymal secretion to prevent accumulation in the cavity, and preserve muscular tonus to avoid anti-symmetrical alterations that might gradually install (1). There are references to globe repairing in the Egyptian, Aztec, Roman and Inca civilizations, using rudimentary artificial eyes manufactured from a wide sort of materials, which attempted to reproduce the lost esthetics.

In view of the great number of patients that suffer from eyeball loss and considering the need for treatments that reestablish esthetics and psychological health, this survey investigated the etiology of ocular globe atrophy or loss in patients assisted at two Schools of Dentistry in São Paulo State, Brazil.

\section{MATERIAL AND METHODS}

A total of 238 patients of both genders and different age groups who had suffered ocular globe atrophy or loss were enrolled in this survey. The volunteers were selected from individuals being treated at the Graduate Maxillofacial Prosthetics Clinic in the Faculty of Dentistry of São José dos Campos (UNESP) and the School of Dentistry of the University of Taubaté (UNITAU), both located in São Paulo State, Brazil.

Information regarding general identification, gender, age, etiology of the atrophy/loss, affected side and type ophthalmologic surgery performed were supplied by the patients and/or collected from their clinical files. Data were recorded on working sheets elaborated for this purpose.

Four types of etiology were considered: congenital (atrophy or loss diagnosed at birth); nonspecific (atrophy or loss of unknown origin); traumatic (when eyeball atrophy or loss was caused by a trauma); and pathogenic (when an infection, tumor or another pathogenic event 
led to ocular globe atrophy or loss).

Patients' age was that at the occasion of surgery for ocular bulb removal or when the diagnosis of atrophy was settled.

Three types of surgery were considered: evisceration (when the inner contents of the eye were surgically removed, leaving the sclera intact); enucleation (when the eyeball was surgically removed, but the eye muscles and remaining orbital contents, intrinsic muscles, optic nerve section and ocular capsule were preserved; and exenteration (when the orbital cavity content was completely removed, often involving resection of the upper and lower eyelids and covering of the epidermic socket with a graft).

The atrophies/losses were classified as left, right or bilateral, regarding their side of occurrence.

The collected data were recorded in appropriate working sheets and examined to assess the frequencies in numbers and percentages of the proposed variables within the studied population. Statistical analysis was performed by analysis of variance and chi-square test.

\section{RESULTS AND DISCUSSION}

The evaluation of the clinical files of all 238 patients enrolled in this study revealed that traumatic etiology was the most frequent cause of atrophy/loss of the ocular globe $(57.14 \%)$, followed by pathogenic (36.13\%) and congenital etiologies (5.04\%) (Table 1).

Regarding the distribution by gender, congenital and traumatic etiologies were more frequently observed in the male population (2.94\% and $41.17 \%$, respectively), while the incidence of pathogenic etiology was higher among female patients (19.32\%). Etiologies of unknown origin were present in $0.84 \%$ of individuals of both genders (Table 1).

Table 1. Incidence of each etiology as a function of gender.

\begin{tabular}{lccc}
\hline Etiology & Male & Female & Total \\
\hline Congenital & 7 & 5 & 12 \\
Traumatic & 98 & 38 & 136 \\
Pathogenic & 40 & 46 & 86 \\
Unknown & 2 & 2 & 4 \\
Total & 147 & 91 & 238 \\
\hline
\end{tabular}

The findings of this survey revealed that in over half of the cases examined eyeball atrophy/loss was caused by traumatic events. These results are consistent with those of previous studies. Madi et al. (2) examined 3008 patients and verified $58.77 \%$ of injuries of traumatic origin and $41.22 \%$ of pathogenic origin. Portellinha et al. (3) evaluated 43 enucleated patients and observed that in $58.13 \%$ of the cases the eyeball was lost due to trauma, while $39.55 \%$ of the subjects lost the ocular globe because of pathogenic causes. Dayal et al. (4) reported that trauma was responsible for $46 \%$ of ocular globe losses occurred in 50 patients. Mattos and Carvalho $(5,6)$ evaluated the records of 548 patients of both genders with ocular globe loss and found that 347 of the cases were cause by some kind of trauma, 175 by pathogenic factors and 26 had congenital or unknown origins. Rode et al. (7) reported that, from 301 patients examined, trauma was as the cause of eyeball loss in $49.16 \%$ of the cases, pathogenies were responsible for $22.92 \%$ of the occurrences, $16.60 \%$ of the cases had unknown etiology and $8.3 \%$ of the patients had congenital anophthalmos. Vangelova (8), in a retrospective survey of the clinical documentation of 35 patients enucleated due to trauma, found that most accidents resulted from housework, while Helbig and Iseli (9) investigated 59 cases of injuries to the ocular bulb caused by cow horns.

On the other hand, our outcomes do not agree with those of some studies in which only a small percentage of the cases of ocular globe loss was attributed to traumatic etiology (10-13). Although some authors have reported that trauma was not responsible for the great number of ocular globe enucleations in their studies, our clinical experience and the findings of most surveyed authors lead us to believe that prevention to ocular globe injuries must be emphasized with special attention to traumas resulting from housework (8).

Facing these results, it is imperative to adopt some preventive measures such as wearing protection eyeglasses during activities that can lead to eyeball injury, use of plated glass in vehicles windshield and building constructions, in addition to stimulate frequent visits to an ophthalmologist.

The present study revealed predominance of losses among male (61.76\%) over female (38.23\%), which agrees with the findings of previous investigations (3,5-7,12-14). These results may possibly be ascribed to the fact that the male population is usually more exposed to situations that can lead to eyeball injury: men 
are still the majority of workers in areas of physical demand and are most commonly involved in traffic accidents and cases of aggression or urban violence).

Regarding the age range, Table 2 shows that there was a predominance of eyeball atrophy/loss in the 21-40 year age group, which corresponded to $42.01 \%$ of the cases. This predominance is probably attributed

Table 2. Incidence of each etiology as a function of age.

\begin{tabular}{lccccccc}
\hline Etiology & \multicolumn{7}{c}{ Ages (years) } \\
\cline { 2 - 8 } & $0-20$ & $21-40$ & $41-60$ & $61-80$ & $\geq 81$ & Unknown & Total \\
\hline Congenital & 3 & 7 & 1 & - & - & 1 & 12 \\
Traumatic & 12 & 61 & 38 & 19 & 5 & 1 & 136 \\
Pathogenic & 17 & 31 & 20 & 9 & 3 & 6 & 86 \\
Unknown & - & 1 & - & 1 & - & 2 & 4 \\
Total & 32 & 100 & 59 & 29 & 08 & 10 & 238 \\
\hline
\end{tabular}

Table 3. Incidence of each etiology as a function of type of surgery.

\begin{tabular}{lccccc}
\hline Etiology & \multicolumn{5}{c}{ Surgery } \\
\cline { 2 - 6 } & Enucleation & Evisceration & Exenteration & Unknow & Total \\
\hline Congenital & 6 & 3 & - & 3 & 12 \\
Traumatic & 96 & 34 & 1 & 5 & 136 \\
Pathogenic & 54 & 25 & 4 & 3 & 86 \\
Unknown & 2 & - & 1 & 1 & 4 \\
Total & 158 & 62 & 6 & 12 & 238 \\
\hline
\end{tabular}

Table 4. Incidence of each etiology as a function of affected side.

\begin{tabular}{lccccc}
\hline Etiology & \multicolumn{5}{c}{ Side } \\
\cline { 2 - 6 } & Left & Right & Both & Unknown & Total \\
\hline Congenital & 6 & 4 & 1 & 1 & 12 \\
Traumatic & 80 & 53 & 2 & 1 & 136 \\
Pathogenic & 42 & 35 & 6 & 3 & 86 \\
Unknown & 3 & 1 & - & - & 4 \\
Total & 131 & 93 & 9 & 5 & 238 \\
\hline
\end{tabular}

to the fact that individuals at this age range have multiple activities and are therefore more exposed to situations that can lead to ocular globe injuries. Mattos and Carvalho $(5,6)$ reported the 21-40 year age group corresponded to $28.8 \%$ of the occurrences but was preceded by the $0-20$ year age group (37.4\%). For individuals aged 40 years or more, a gradual decline of cases of ocular globe loss is observed due not only to the reduction of activity, but also to a greater conscience of life. Gunalp et al. (13), in a study with 3482 patients, reported that $53.6 \%$ of them were aged 30 years or less. Viestenz and Kuchle (14) found that, in a study population of 417 individuals, $85 \%$ were in the 10-29 year age group. A review of literature showed that only one author (12) reported greater number of patients under 15 years old (85.2\%) among individuals who had undergone ocular globe atrophy/ loss.

In this study, the review of the types of surgery most often performed for removal of the ocular globe showed a predominance of enucleation (66.38\%) followed by evisceration (26.05\%) and exenteration (2.52\%) (Table 3). These outcomes are in accordance with those of previous studies $(5,6)$, which also found enucleation as the most frequently chosen type of surgical procedure. Nevertheless, the type of ophthalmologic surgery changes depending on the etiology of the injury. In cases of pathogenic etiology, enucleation is performed twice more frequently than evisceration and the variations in frequencies are similar for both genders.

Regarding the affected side, a predominance of the left side (55.04\%) over the right side (39.07\%) was observed (Table 4), even though these data did not present statistically significant difference ( $\mathrm{p}>0.01)$. Similar results have been reported (7). On the other hand, Mattos and Carvalho $(5,6)$ have not found side predominance in a study with 548 patients. Therefore, in view of these results, the side does not seem to be an 
important issue to be considered in preventive and educative campaigns.

Ocular trauma is a leading cause of severe anatomic and functional impairment of the visual system. The issues discussed in this survey emphasized the high incidence and frequent severity of eye injuries in young adults causing ocular bulb loss. Prevention, as mentioned above, should be the primary goal. Fortunately, today, thanks to remarkable advances in ocular implants, the loss of an eye no longer has to mean the loss of the natural appearance. However, for successful prosthetic rehabilitation it is important to know the etiology of the ocular globe loss in order to render the most suitable therapeutic and surgical approach.

\section{RESUMO}

Este estudo investigou a etiologia dos casos de atrofia e perda do globo ocular em pacientes atendidos no ambulatório de prótese buco-maxilo-facial de duas Faculdades de Odontologia do estado de São Paulo. Um total de 238 pacientes e seus prontuários foram examinados, e a etiologia e incidência dos casos de atrofia e perda do globo ocular foram avaliados considerando gênero, faixa etária, lado afetado e tipo de cirurgia oftalmológica realizada. As perdas por etiologia traumática foram as de maior incidência (57,14\%), seguidas das perdas por etiologia patogênica $(36,13 \%)$ e com menor incidência para as perdas por causas congênitas (5,04\%). Comparando-se os gêneros, houve predominância da população masculina (61.76\%; $<<0,01)$. A faixa etária mais freqüentemente atingida foi a de 21 a 40 anos $(42.01 \%$; p <0,01). Em todas as etiologias estudadas, a cirurgia mais empregada para remoção do globo ocular foi a enucleação (66.38\%; p<0,01). Houve predominância da perda do globo ocular do lado esquerdo (55.04\%), mas não houve diferença estatisticamente significante.

\section{ACKNOWLEDGEMENTS}

We would like to thank Mr. Fernando Antônio Elias Claro for assistance with statistical analysis. This work was supported by FAPESP (grant N. 98/07017-4).

\section{REFERENCES}

1. Perrone A, Bercini F, Azambuja TWF. Prótese ocular, revisão da literatura e apresentação de caso clínico. Rev Fac Odont Porto Alegre 1996;37:13-14.

2. Madi JL, Paiola D, Rode R. Etiologia das lesões oculars. Rev Fac Franc 1983;1:53-71.

3. Portellinha WM, Belfort Jr R, Cai S, Novo NF. Estudo clínicomicrobiológico citológico e de função lacrimal em pacientes com cavidade anoftálmica e uso de prótese ocular de acrílico. Arq Bras Oftalmol 1984;47:159-163.

4. Dayal Y, Rao SS, Mahagan VM. Comparative study of bacterial and fungal floras of contracted sockets and fellow eyes. Ann Ophthal 1984;16:154-162.

5. Mattos BSC, Carvalho JCM. Prevalência das perdas do globo ocular. II. Estudo da variável idade e de suas correlações com a etiologia, sexo e cirurgia oftalmológica. Rev Fac Odont Univ S Paulo 1989;3:246-252.

6. Mattos BSC, Carvalho JCM. Prevalência das perdas do globo ocular. III. estudo da variável cirurgia e suas correlações com a etiologia e o sexo. Rev Fac Odont Univ S Paulo 1989;3:284288.

7. Rode R, Varella MA, Rode SM. Etiologia da perda do globo ocular, parcial ou total, que leva à indicação de prótese. Rev ABO Nac 1997;5:362-365.

9. Helbig H, Iseli HP. Traumatic rupture of the globe caused by cow horns. Eur J Ophthalmol 2002;12:304-308.

10. Christensen JN, Fahmy JA. The bacterial flora of the conjunctival anophthalmic socket in glass prosthesis-carriers. Acta Ophthal 1974;52:801-809.

11. Rao AV, Sood GC, Reddy S. Bacteriology on the socket. East Arch Ophthal 1977;5:66-69.

12. Vemuganti GK, Jalali S, Honavar SG, Shekar GC. Enucleation in a tertiary eye care centre in India: prevalence, current indications and clinicopathological correlation. Eye 2001;15:760-765.

13. Gunalp I, Gunduz K, Ozkan M. Causes of enucleation: a clinicopathlogical study. Eur J Ophthalmol 1997;7:223-228.

14. Viestenz A, Kuchle M. Retrospective analysis of 417 cases of contusion and rupture of the globe with frequent avoidable causes of trauma: the Erlangen Ocular Contusion - Registry. Klin Monatsbl Augenheilkd. 2001;218:662-669.

Accepted November 24, 2003 